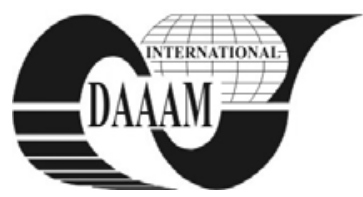

Annals of DAAAM for 2011 \& Proceedings of the 22nd International DAAAM Symposium, Volume 22, No. 1, ISSN 1726-9679 ISBN 978-3-901509-83-4, Editor B. Katalinic, Published by DAAAM International, Vienna, Austria, EU, 2011 Make Harmony between Technology and Nature, and Your Mind will Fly Free as a Bird

\title{
HYBRID SOLUTIONS FOR THE AUTONOMY OF A MODERN TELECOMMUNICATIONS SITE
}

\section{GANSCA, S[ebastian] G[heorghe]; ROSCA, R[obert]; SAPARIUC, F[lorin]; TRIF, T[udor] N[icolae] \& TRIF, I[acob] N[icolae]}

Abstract: To increase efficiency, safety in operation, a telecommunications site consisting of radio station responsive, it should be permanent and self-powered electricity to power imposed. The paper presents two modern solutions for electric power supplied from wind turbines and solar electric panels. Both of them can provide sufficient power for the antennae and its equipment

Key words: telecommunications site, antennas, wind, solar

\section{INTRODUCTION}

Good operation, framing parameters transceiver station and the transmission quality depends on a telecommunications site, placed in isolation in the field of safety control and power supply. Thus it is proposed the use of hybrid and alternative power solutions using telecommunications antenna structure underlying the site.

\section{THE STRUCTURE OF A TELECOMMUNICATIONS SITE}

A transmission for mobile communications site contains the following elements:

- $\quad$ Radio base station (RBS / RNC);

- $\quad$ Cabinet for electric batteries (PBC);

- Cabinet broadcast (TMR);

- External alarm connection unit (EACU);

- $\quad$ Air conditioning (A / C);

- Telecomunications antennae;

- Cable sets for connexions.

Figure 1 shows the main elements of a transmission site for mobile telecommunications.( Fujimoto, 2001)

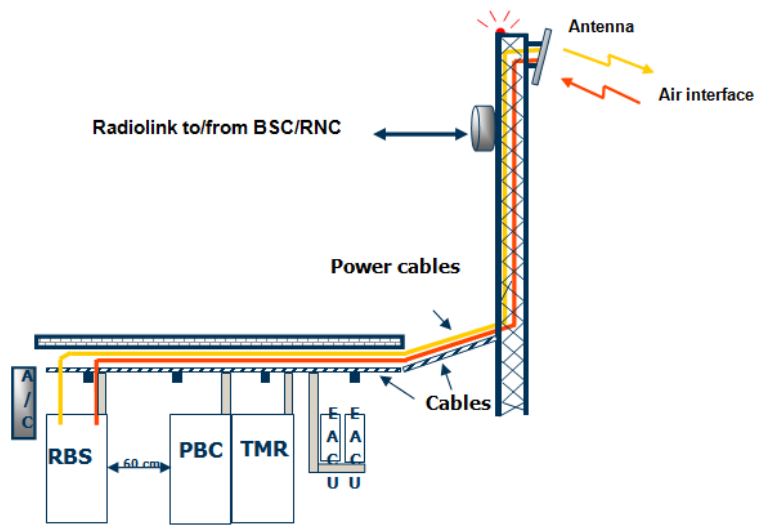

Fig. 1. A transmission site for mobile communications

\section{SOLUTIONS HYBRID POWER SUPPLY}

When designing a site for mobile telecommunications service provider has several options for power. Choosing the optimal solution depends on local circumstances and may include: power supply, power generation using fuel, wind power or solar energy.

Technologies for producing electricity from wind energy are increasingly used. They can be considered as additional sources of supply due to the site location in difficult locations. Energy costs continue to drop and it becomes increasingly more efficient. Wind alternative energy solutions are available at affordable prices and almost anywhere.( Johnson, 1993)

In the projection phase we take into consideration a number of elements for the selection of wind turbines: capacity, location. Maximum wind speeds defines the antenna structure where the turbine is mounted since there is a direct relationship between height from the ground and wind speed. Low-power turbine can be mounted on the highest telecommunications tower but a high power turbine needs to be mounted on a lower tower height with greater resistance. (Josefsson, 2006)

Figure 2 shows how to fit a wind turbine on a steel type telecommunication antennae tower.

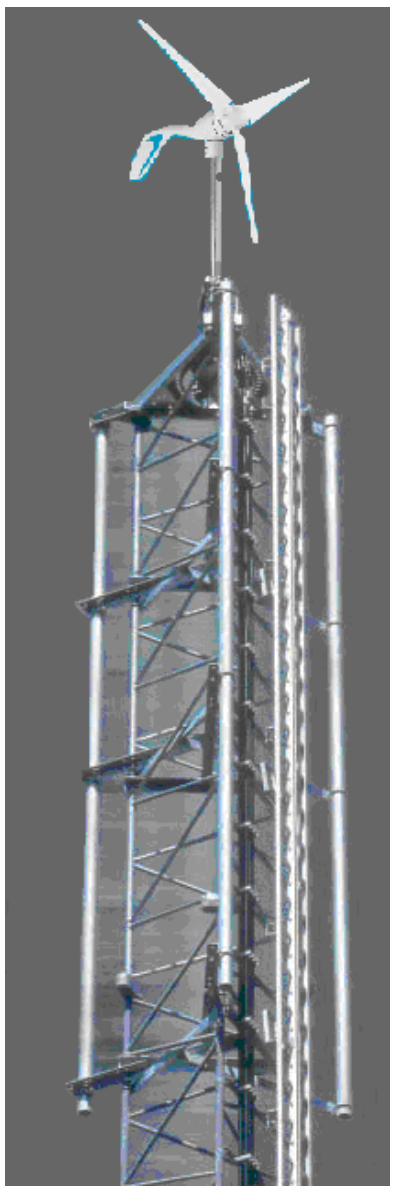

Fig. 2. Wind turbine tower mounted on metal

To store the electricity batteries are used in series and powered by a regulator like in Figure 3. 
To increase the installed power more wind turbines can be coupled in parallel. Power supply telecommunication system is obtained from an inverter. There are provided some protection systems and control the voltage supplied.

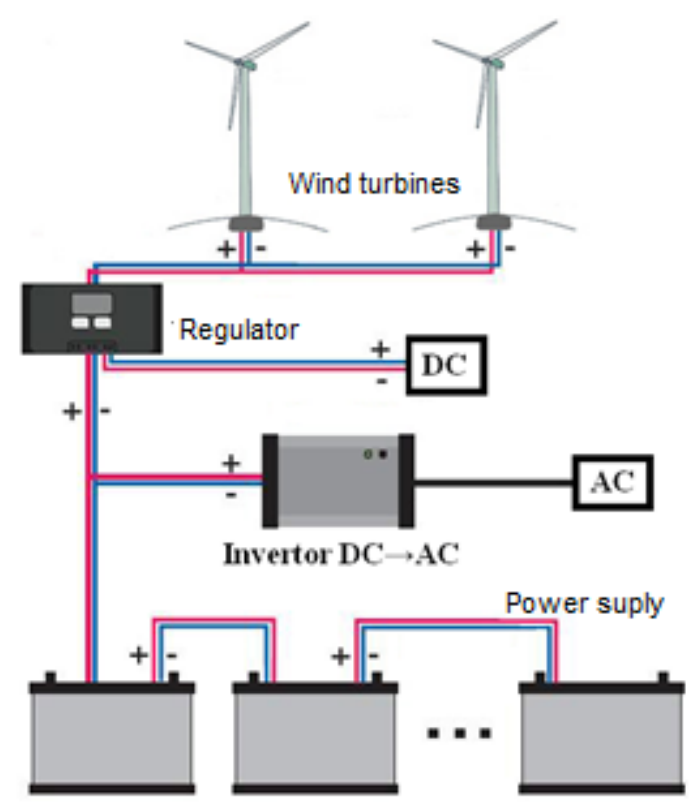

Fig. 3. Wind system configuration

Another alternative solution is to use solar cells embedded in panels that can be mounted on the telecommunications antennae. (Rosca, 2010)

Figure 4 shows how the installation of solar panels on a metal tower telecommunications is made. (Stottrup-Andersen, 2005)

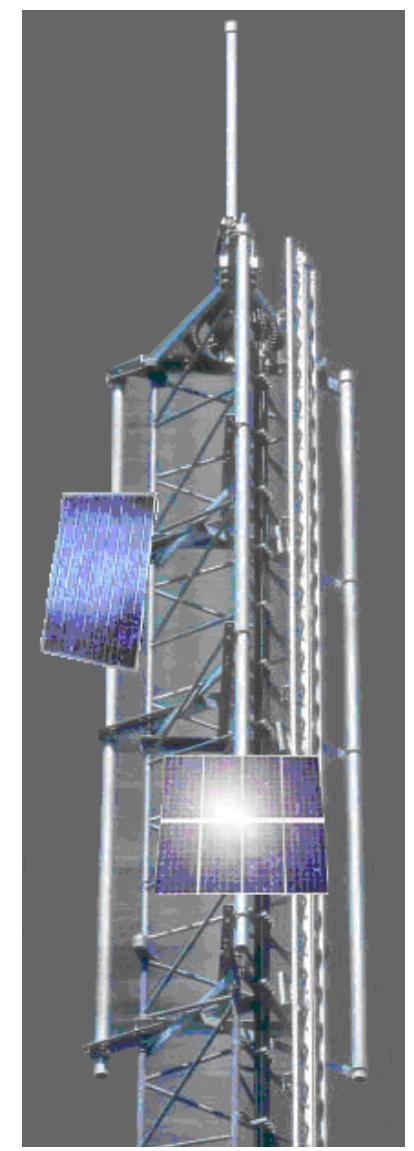

Fig. 4. Solar panels installed on the metal tower
Electricity produced by photovoltaic cells is stored in batteries using a system of series inverters in Figure 5.

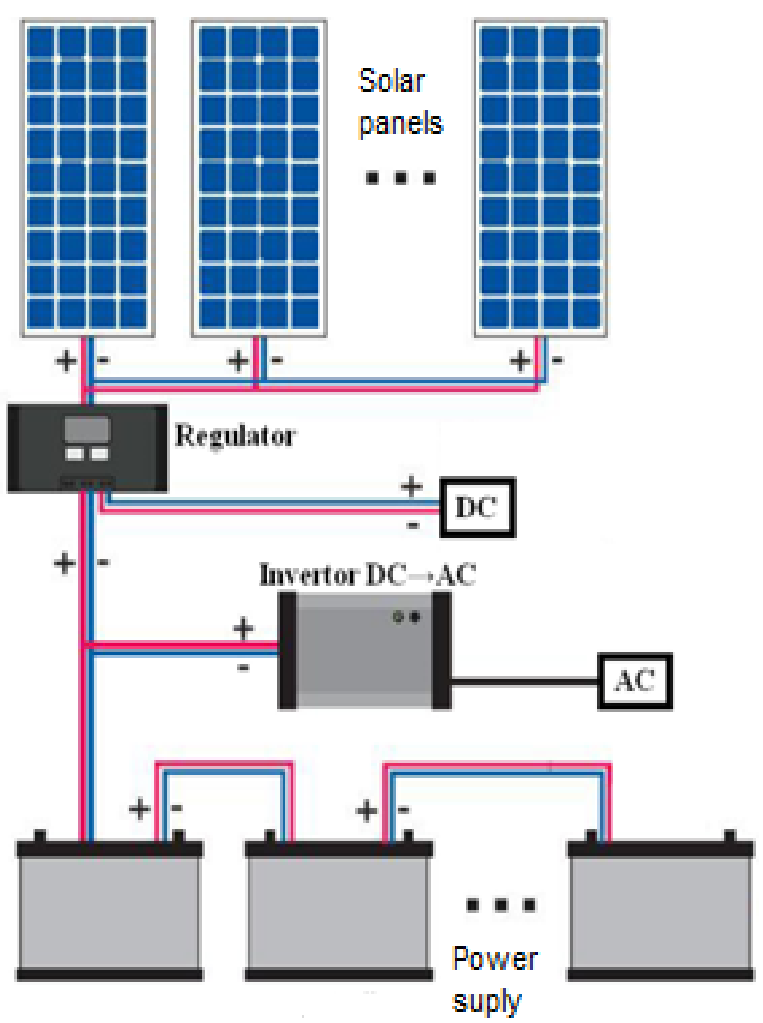

Fig. 5. Solar power system configuration

To increase the power generated by solar electric panels these are coupled in series. Power supply system is obtained using a power inverter.

\section{CONCLUSION}

The use of hybrid solutions for power supply increases the autonomy of the telecommunications site. Using wind and solar is competitive and reliable ecological solution. Turbines and solar panels can be mounted on the telecommunications antennae with simple constructive solutions. Thus increase the effectiveness and the multifunctional role of a telecommunications antenna. Both systems can provide enough power for the antennae and its equipment and there is no need for third party power suply.

\section{ACKNOWLEDGEMENTS}

This paper is supported by the Sectoral Operational Programme Human Resources Development (SOP HRD), ID76945 financed from the European Social Fund and by the Romanian Government

\section{REFERENCES}

Fujimoto, Mobile Antenna Systems Handbook, Artech House, 2001

Johnson, R. C., Antenna Engineering Handbook, 3rd Edition, McGraw-Hill, 1993

Josefsson, L., and Persson, P., The Array Antenna Theory and Design, IEEE New York, Wiley, 2006

Rosca, R., C., Towers and masts for telecommunications, AGIR Bulletin, 2010

Stottrup-Andersen, U., Masts and Towers for the UMTS Network in Sweden, EuroSteel 2005, Maastricht, Nederland, June 2005 